\title{
A Survey of Bovine Colostrum Composition and Colostrum Management Practices on Pennsylvania Dairy Farms ${ }^{1}$
}

\author{
S. I. Kehoe, ${ }^{\star 2}$ B. M. Jayarao, $†$ and A. J. Heinrichs ${ }^{\star 3}$ \\ *Department of Dairy and Animal Science, and \\ †Department of Veterinary and Biomedical Sciences, The Pennsylvania State University, University Park 16802
}

\begin{abstract}
Colostrum composition and management were surveyed via sample and data collection from 55 dairy farms in Pennsylvania. Colostrum samples were analyzed for fat, protein, lactose, total solids, ash, Ig, lactoferrin, water- and fat-soluble vitamins, and minerals. Mean percentages of fat, protein, and lactose in colostrum were $6.7,14.9$, and 2.5 , respectively. Concentrations of $\operatorname{IgG}_{1}, \operatorname{IgG}_{2}, \operatorname{IgA}$, IgM, and lactoferrin were 35.0, $6.0,1.7,4.3$, and $0.8 \mathrm{mg} / \mathrm{mL}$, respectively. Mean concentrations of fat-soluble vitamins, including retinol, tocopherol, and $\beta$-carotene, were $4.9,2.9$, and $0.7 \mu \mathrm{g} / \mathrm{g}$, respectively. Mean concentrations of water-soluble vitamins were $0.34,0.90,4.55,0.60,0.15,0.21$, and 0.04 $\mu \mathrm{g} / \mathrm{mL}$ for niacin, thiamine, riboflavin, vitamin $B_{12}$, pyridoxal, pyridoxamine, and pyridoxine, respectively. Mean concentrations $(\mathrm{mg} / \mathrm{kg})$ of selected minerals in colostrum were also determined (Ca 4,716; P 4,452; Mg 733; Na 1,058; K 2,845; Zn 38; Fe 5.3; Cu 0.3; S 2,595; and Mn 0.1). The findings of this study revealed that the mean concentrations of most nutrients in colostrum have increased when compared with values previously reported. Results also showed that management practices have improved over time, particularly with regard to colostrum storage and feeding. Additionally, we observed that herd size influenced colostrum management and quality. It can be inferred, based on these findings, that although improvements have been made with regard to colostrum management and quality, there is still a need to educate producers on issues related to storage and timely feeding of colostrum to increase passive transfer and decrease the rate of calf morbidity and mortality.
\end{abstract}

Received January 20, 2007.

Accepted May 2, 2007.

${ }^{1}$ This research was a component of NC-1119: Management Systems to Improve the Economic and Environmental Sustainability of Dairy Enterprises.

${ }^{2}$ Current address: University of Wisconsin-River Falls, Dept. of Animal Science, 242 Agricultural Science Bldg., 410 S. 3rd St., River Falls, WI 54022.

${ }^{3}$ Corresponding author: ajh@psu.edu
Key words: colostrum composition, colostrum management, dairy calf, Pennsylvania

\section{INTRODUCTION}

Management and feeding of high-quality colostrum can reduce calf mortality, strengthen immunity, and increase animal life span (Quigley and Drewry, 1998). Delaying the intake of colostrum reduces passive transfer of Ig and postpones provision of essential nutrients that supplement the meager reserves in the bovine neonate.

The composition of colostrum is important in satisfying the nutritional requirements of neonatal dairy calves, particularly for nutrients that only minimally cross the placenta, such as fat-soluble vitamins (Spielman et al., 1946). Calves also require fat and protein for energy and muscle development in the first days of life, as well as growth factors and many other nutrients that are concentrated in the first lacteal secretions of the dam postcalving (Roy, 1990; Quigley and Drewry, 1998). Despite the importance of nutrients in colostrum, published data describing bovine colostrum composition are extremely limited. Foley and Otterby (1978) reviewed the literature on bovine colostrum composition nearly $30 \mathrm{yr}$ ago; however, to our knowledge, no comprehensive research on colostrum composition has been published since then.

Most research investigating colostrum focuses narrowly on IgG and ignores other Ig and nutrients. In addition, limited work has examined the relationship between the nutritive values of colostrum and management practices. Recently, Zanker et al. (2000) showed that calves receiving colostrum 12 to $25 \mathrm{~h}$ after birth had lower plasma concentrations of $\beta$-carotene, retinol, and $\alpha$-tocopherol for nearly a month after birth compared with calves that received colostrum within $7 \mathrm{~h}$ of birth. Although IgG transfer is the most important factor affecting calf health and survival, it is possible that the exclusive focus on IgG has obscured the value of other components of colostrum. Elucidation of normal levels of these other components and examination of the impact of management practices on them may provide 
additional routes for improving calf health. This information has particular application to the formulation of colostrum supplements and replacers.

It is well established that management practices affect morbidity, mortality, and passive transfer of immunity in dairy calves. According to the 2002 report of the US National Animal Health Monitoring System (NAHMS), $30.5 \%$ of producers still provide colostrum by allowing calves to nurse their dams (USDA, 2002). By comparison, this number was $33.7 \%$ in the 1991 NAHMS survey. However, this is a significant improvement from a 1973 survey, which showed that $77 \%$ of Michigan dairies allowed calves to nurse their dams (Speicher and Hepp, 1973). Farms in Pennsylvania that separate calves and feed colostrum manually, either by bottle or tube, reported an average of $2.7 \mathrm{~h}$ until calves were fed first colostrum after birth (Heinrichs et al., 1987). Swedish farmers reported the first colostrum feeding within an average of $3 \mathrm{~h}$ after birth (Svensson et al., 2003), whereas only $60 \%$ of Alberta farms fed calves within $4 \mathrm{~h}$ of birth.

The most recent survey of colostrum management and calf care in Pennsylvania was published 20 yr ago (Heinrichs et al., 1987). Over the last 3 decades, dairy management and nutrition practices, and nutrient analysis techniques have changed considerably. This necessitates the evaluation of bovine colostrum composition and colostrum management practices in light of the many changes in the dairy industry. The first objective of the current study was to record methods used for handling, storing, feeding, and managing colostrum on Pennsylvania farms. The second objective was to analyze the nutrient composition and contents of colostrum in comparison with other research. This analysis of colostrum management and nutrient content will enable the identification of areas in need of improvement to allow for the increased survival of dairy calves.

\section{MATERIALS AND METHODS}

\section{Description of Questionnaire and Herds}

A questionnaire was developed to obtain information about the management of colostrum, which included milking procedures, storage of colostrum, and treatment protocols. Calf feeding questions included time of feeding after birth, volume fed, and feeding method. The prototype questionnaire was field tested, after which redundancies and unclear questions were modified. The refined 33-item questionnaire was administered by a single interviewer and required about 15 min for completion. All procedures were approved by the Human Subjects Review Committee at The Pennsylvania State University, and all subjects gave informed, written consent.
A representative sample consisting of 55 Holstein dairy herds in 15 Pennsylvania counties were surveyed for colostrum management practices, and colostrum samples were collected from these farms for determination of colostrum composition. The 15 counties selected accounted for nearly $90 \%$ of all dairy operations in Pennsylvania because of industry concentration in the 4 regions surveyed (Pennsylvania Agricultural Statistical Report, 2003). Colostrum samples were collected and surveys administered from July 2004 through March 2005.

\section{Determination of Colostrum Composition}

Processing of Colostrum for Analysis. Producers were asked to retain a sample of colostrum within $3 \mathrm{~d}$ of the on-farm interview. One cow per farm was fully milked out within $4 \mathrm{~h}$ of calving, and colostrum was mixed thoroughly, sampled into a container, and then refrigerated. Samples were then transported on ice to the laboratory, where eleven $25-\mathrm{mL}$ aliquots of each sample were taken and stored at $-20^{\circ} \mathrm{C}$ for later analyses.

Ig and Lactoferrin. Immunoglobulins $\mathrm{G}_{1}, \mathrm{G}_{2}, \mathrm{M}$, and $\mathrm{A}$ were analyzed by radial immunodiffusion (RID) (Kits E10-116, 117, 118, 121, and 101, Bethyl Laboratories, Montgomery, TX). Colostrum dilutions were made with saline and consisted of 4-fold dilutions for IgA and IgM, a 10-fold dilution for $\operatorname{IgG}_{1}$, and a 2 -fold dilution for $\mathrm{IgG}_{2}$. All samples and kits were brought to room temperature and samples were thoroughly mixed before use. Because of the viscous nature of colostrum, each assay was controlled with a BSA standard as well as an aliquot of colostrum from the same cow to ensure that kits were within the appropriate range of the standards. A regression coefficient of $95 \%$ or higher was used to ensure the accuracy of assays. Lactoferrin was analyzed by ELISA (Kit E10-126, Bethyl Laboratories).

Vitamins. $\beta$-Carotene, retinol, and tocopherol were extracted according to methods from Vitamin Analysis for the Health and Food Sciences (Eitenmiller and Landen, 1999) and analyzed by HPLC techniques as described by Arnaud et al. (1991). Water-soluble vitamins, including niacin, pyridoxal, pyridoxine, pyridoxamine, folic acid, riboflavin, vitamin $\mathrm{B}_{12}$, and thiamin, were analyzed by the HPLC method described by AlbalaHurtado et al. (1997) at the Proteomics Facility of the Huck Institutes of the Life Sciences at The Pennsylvania State University.

Minerals. One aliquot of colostrum was freeze-dried and analyzed for $\mathrm{Ca}, \mathrm{P}, \mathrm{Na}, \mathrm{K}, \mathrm{Mg}, \mathrm{Mn}, \mathrm{Fe}, \mathrm{Cu}, \mathrm{Zn}$, and S by Environmental Protection Agency (EPA) method 3051 to microwave digest samples with nitric acid. After digestion, samples were analyzed by EPA method 6010 
with inductively coupled plasma spectrometry (US EPA, 1986).

Fat, Lactose, and Protein. Fat was analyzed according to the Babcock procedure as described in Standard Methods for the Examination of Dairy Products (Wehr and Frank, 2004), and lactose was analyzed following the method of Feitosa Teles et al. (1978). Crude protein was analyzed by Kjeldahl analysis and corrected by using a factor of 6.38. Total solids and ash were analyzed following AOAC methods (1975).

\section{Statistical Analysis}

The GLM procedure of SAS 8.2 (SAS Institute, 2002) was used to analyze differences between nutrients and survey data. Questions, nutrients, and correlations were also analyzed by herd size, with herds categorized as small ( $\leq 100$ cows; $n=17$ ), medium (101 to 200 cows; $n=10)$, or large ( $\geq 201$ cows; $n=28)$ based on the number of cows. Each nutrient analysis was correlated with all 33 survey questions by using the GLM procedure; significance was declared at $P<0.05$ and trends at $P$ $<0.15$.

\section{RESULTS AND DISCUSSION}

\section{Colostrum Composition}

The compositional analysis of colostrum content from samples collected from cows in Pennsylvania is presented in Table 1 . The findings of our study were compared with the concentrations reported by Foley and Otterby (1978), the last published review of colostrum composition. Components such as lactoferrin and individual IgG subclasses were analyzed in the current study but were not reported by Foley and Otterby (1978) because of the lack of an adequate methodology for analyzing these components at that time. For nutrient composition, 55 samples were analyzed, except for fat, for which 1 sample was not recorded; only 23 mineral samples of manganese were quantified because the other samples were too low to quantify. Fifty-four samples were analyzed for water-soluble vitamins; only 5 samples were quantifiable for vitamin $\mathrm{B}_{12}$ and pyridoxine.

Fat was measured at an average of $6.7 \pm 4.2 \%$, which was similar to previous reviews. Parrish et al. (1950), who measured fat by using the same procedure (Babcock) as in the current review, reported a value of 6.7 $\pm 2.7 \%$. Fat content in colostrum is less likely to be affected by feeding different levels of dietary fat during gestation (Dietz et al., 2003).

Protein $(14.9 \pm 3.3 \%)$ concentration in colostrum was also similar between reviews, further illustrating the lack of influence of dietary factors. Researchers have reported that beef heifers restricted in protein intake gained less weight during the last trimester, with no effect on colostrum energy and protein content (Carstens et al., 1987).

Mean lactose content was $2.5 \pm 0.7 \%$ and was similar to other reports (Parrish et al., 1950). Lactose concentrations are reduced in colostrum and act inversely of other constituents, such as solids, protein, and ash, which are all found in high concentrations and decrease over time. This coincides with the physiology of the neonate calf, in which lactase is found in low concentrations at birth and increases over time (Zabielski et al., 1999).

The concentration of $\mathrm{IgG}_{1}$ was $34.9 \pm 12.2 \mathrm{mg} / \mathrm{mL}$, which was higher than the report by Foley and Otterby (1978) of $32 \mathrm{mg} / \mathrm{mL}$ of total IgG, of which $\mathrm{IgG}_{1}$ was approximately $85 \%$. In other more recent work, Pritchett et al. (1991) found an average of $48.2 \pm 28.9 \mathrm{mg} / \mathrm{mL}$ for $\mathrm{IgG}_{1}$, indicating the need for improving colostrum Ig concentrations. Previous research has indicated that nutrient availability prepartum does not significantly affect the colostrum IgG content. Halliday et al. (1978) reported no differences in colostrum IgG and total protein content when beef cows were fed 12 wk before parturition on diets ranging from 65 to $125 \%$ of maintenance for 2 consecutive years.

Other factors do play a role in the Ig content of colostrum. The volume of colostrum produced, parity, dry period length, vaccination, and many other factors have been reviewed and have been reported to affect the IgG content (Weaver et al., 2000). Any of these factors may have played a role in accounting for the low IgG content of some samples in the current survey, although without knowing which factors were different, they could not be accounted for in this survey.

Concentrations of IgA in the current study were much lower than those in previous research. In the current survey, IgA was obtained by RID; however, in other studies microdiffusion discs were used (Masseyeff and Zisswiller, 1969). Because of the low concentrations of IgA and the high solids content of bovine colostrum, the specificity and sensitivity of the RID may have been slightly altered. Most studies have reported values between 3 and $4 \mathrm{mg} / \mathrm{mL}$ (Porter, 1972), whereas the current survey reports a value of $1.66 \mathrm{mg} / \mathrm{mL}$.

Concentrations of IgM for the current study (4.32 mg/ $\mathrm{mL}$ ) fall within the range of literature values because of the high variation of IgM concentrations, which ranged anywhere from 3 to $12 \mathrm{mg} / \mathrm{mL}$. Variation in IgM as well as IgA also may be influenced by parity, breed, vaccinations, health status, and other factors, similar to IgG (Porter, 1972). Furthermore, there is currently a need for more reliable and repeatable assays that can take into account the high solids content of colostrum. 
Table 1. Compositional analysis of colostrum from samples collected from cows in Pennsylvania

\begin{tabular}{|c|c|c|c|c|c|c|}
\hline Item & $\mathrm{n}$ & Mean & SE & Minimum & Maximum & $\begin{array}{c}\text { Foley and } \\
\text { Otterby (1978) }\end{array}$ \\
\hline Fat, \% & 54 & 6.70 & 4.16 & 2.0 & 26.5 & 6.7 \\
\hline Protein, \% & 55 & 14.92 & 3.32 & 7.1 & 22.6 & 14.0 \\
\hline Lactose, \% & 55 & 2.49 & 0.65 & 1.2 & 5.2 & 2.7 \\
\hline Total solids, \% & 55 & 27.64 & 5.84 & 18.3 & 43.3 & 23.9 \\
\hline Ash, \% & 55 & 0.05 & 0.01 & 0.02 & 0.07 & - \\
\hline $\mathrm{IgG}, \mathrm{mg} / \mathrm{mL}$ & - & - & - & - & - & 32.0 \\
\hline $\mathrm{IgG}_{1}, \mathrm{mg} / \mathrm{mL}$ & 55 & 34.96 & 12.23 & 11.8 & 74.2 & - \\
\hline $\mathrm{IgG}_{2}, \mathrm{mg} / \mathrm{mL}$ & 55 & 6.00 & 2.82 & 2.7 & 20.6 & - \\
\hline IgA, mg/mL & 55 & 1.66 & 0.99 & 0.5 & 4.4 & - \\
\hline IgM, mg/mL & 55 & 4.32 & 2.84 & 1.1 & 21.0 & - \\
\hline Lactoferrin, $\mathrm{mg} / \mathrm{mL}$ & 55 & 0.82 & 0.54 & 0.1 & 2.2 & - \\
\hline Retinol, $\mu \mathrm{g} / \mathrm{g}$ & 55 & 4.90 & 1.82 & 1.4 & 19.3 & 2.8 \\
\hline Tocopherol, $\mu \mathrm{g} / \mathrm{g}$ & 55 & 2.92 & 3.65 & 0.6 & 10.4 & - \\
\hline$\beta$-Carotene, $\mu \mathrm{g} / \mathrm{g}$ & 55 & 0.68 & 0.63 & 0.1 & 3.4 & - \\
\hline Vitamin $E, \mu g / g$ of fat & 55 & 77.17 & 33.51 & 24.2 & 177.9 & 84.0 \\
\hline Thiamin, $\mu \mathrm{g} / \mathrm{mL}$ & 54 & 0.90 & 0.28 & 0.3 & 2.1 & 0.58 \\
\hline Riboflavin, $\mu \mathrm{g} / \mathrm{mL}$ & 54 & 4.55 & 0.31 & 2.4 & 9.2 & 4.83 \\
\hline Niacin, $\mu \mathrm{g} / \mathrm{mL}$ & 54 & 0.34 & 1.57 & 0.0 & 1.6 & 0.96 \\
\hline Vitamin $\mathrm{B}_{12}, \mu \mathrm{g} / \mathrm{mL}$ & 5 & 0.60 & 0.35 & 0.2 & 1.1 & 0.05 \\
\hline Folic acid, $\mu \mathrm{g} / \mathrm{mL}$ & - & - & - & - & - & 0.01 \\
\hline Pyridoxal, $\mu \mathrm{g} / \mathrm{mL}$ & 54 & 0.15 & 0.07 & 0.1 & 0.3 & - \\
\hline Pyridoxamine, $\mu \mathrm{g} / \mathrm{mL}$ & 54 & 0.21 & 0.07 & 0.1 & 0.5 & - \\
\hline Pyridoxine, $\mu \mathrm{g} / \mathrm{mL}$ & 5 & 0.04 & 0.07 & 0.0 & 0.2 & - \\
\hline Pantothenic acid, $\mu \mathrm{g} / \mathrm{mL}$ & - & - & - & - & - & 1.7 \\
\hline $\mathrm{Ca}, \mathrm{mg} / \mathrm{kg}$ & 55 & $4,716.10$ & $1,898.00$ & $1,775.1$ & $8,593.5$ & $2,599.9$ \\
\hline $\mathrm{P}, \mathrm{mg} / \mathrm{kg}$ & 55 & $4,452.10$ & $1,706.29$ & $1,792.4$ & $8,593.5$ & - \\
\hline $\mathrm{Mg}, \mathrm{mg} / \mathrm{kg}$ & 55 & 733.24 & 286.07 & 230.3 & 1,399.6 & 399.9 \\
\hline $\mathrm{Na}, \mathrm{mg} / \mathrm{kg}$ & 55 & $1,058.93$ & 526.02 & 329.7 & $2,967.8$ & 699.9 \\
\hline $\mathrm{K}, \mathrm{mg} / \mathrm{kg}$ & 55 & $2,845.89$ & $1,159.89$ & 983.2 & $5,511.4$ & $1,399.9$ \\
\hline $\mathrm{Zn}, \mathrm{mg} / \mathrm{kg}$ & 55 & 38.10 & 15.90 & 11.2 & 83.6 & 11.6 \\
\hline $\mathrm{Fe}, \mathrm{mg} / \mathrm{kg}$ & 55 & 5.33 & 3.09 & 1.7 & 17.5 & 1.9 \\
\hline $\mathrm{Cu}, \mathrm{mg} / \mathrm{kg}$ & 55 & 0.34 & 0.14 & 0.13 & 0.64 & 0.6 \\
\hline $\mathrm{S}, \mathrm{mg} / \mathrm{kg}$ & 55 & $2,595.67$ & 904.97 & 889.4 & $4,143.7$ & - \\
\hline $\mathrm{Mn},{ }^{1} \mathrm{mg} / \mathrm{kg}$ & 23 & 0.10 & 0.11 & 0.0 & 0.36 & 0.2 \\
\hline
\end{tabular}

${ }^{1}$ Part of the samples were quantified as $<0.05$ and therefore not included in averages.

Lactoferrin is a glycoprotein that binds iron and has been shown to reduce morbidity and improve growth in neonatal dairy calves (Robblee et al., 2003). As analyzed by ELISA in the current study, lactoferrin averaged $0.82 \pm 0.54 \mathrm{mg} / \mathrm{mL}$. Bovine colostrum contains lower lactoferrin concentrations than other species; Yoshida et al. (2000) reported an average of $0.34 \pm 0.23$ $\mathrm{mg} / \mathrm{mL}$ for 6 cows by using chromatography. In contrast, Tsuji et al. (1990) reported an average of $1.96 \pm$ $0.27 \mathrm{mg} / \mathrm{mL}$ for 45 Holstein cows by RIA. Differences may exist because of laboratory techniques; however, bovine colostrum does contain lower lactoferrin concentrations than other species (Masson and Heremans, 1971).

Fat-soluble vitamins are an important component in colostrum. Although tocopherols pass through placental membranes and are stored by the fetus, neonates are still born with low tocopherol levels and rely on colostrum for this nutrient (Zanker et al., 2000). The results for fat-soluble vitamin concentrations in colostrum were similar between reports; however, retinol concentrations were numerically higher in the current survey compared with that of Foley and Otterby (1978). This may be due to the high variation in concentrations of fat-soluble vitamins among individuals as well as the dependence on maternal reserve status, diet, and season. Recently, more emphasis has been placed on dry cow nutrition, which may result in higher fat-soluble vitamin concentrations in colostrum because increased dietary levels also increase colostrum levels (Weiss et al., 1990). Stewart and McCallum (1938) reported variations in retinol ranging from 35 to $1,181 \mathrm{IU} / 100 \mathrm{~mL}$ of colostrum among individual cows on the same management system; this result highlights intersample variation. Many other studies have not used fat concentrations when analyzing fat-soluble vitamin concentrations, which can affect the results because of their high correlation. Weiss et al. (1990) found a significant correlation between fat in colostrum and fat-soluble vitamin concentrations.

Water-soluble vitamins have not been extensively analyzed in colostrum. Before HPLC, researchers at- 
tempting these analyses used methods such as rat growth and a variety of microbiological, chemical, and fluorometric assays, which resulted in variability among assays and technicians. For example, Roderuck et al. (1945) reported a $20 \%$ increase in riboflavin content with microbiological assays compared with fluorometric analysis because of the difficulty of replicating microbiological methods. The means of water-soluble vitamins analyzed by HPLC for the current study were $0.34,0.90,4.55,0.60,0.15,0.21$, and $0.04 \mu \mathrm{g} / \mathrm{mL}$ for niacin, thiamin, riboflavin, vitamin $\mathrm{B}_{12}$, pyridoxal, pyridoxamine, and pyridoxine, respectively. However vita$\min B_{12}$ and pyridoxine were quantifiable in only 5 farm samples. The review by Foley and Otterby of data before 1978 included pantothenic acid and folate, which were not analyzed in the current study. Data from the past review were much lower for concentrations of thiamin and vitamin $\mathrm{B}_{12}$, higher for niacin, and similar for riboflavin. Some past research used values of thiamin, niacin, and riboflavin from pooled colostrum of Holsteins and Jerseys, with methods ranging from microbiological and fluorometric to enzymatic methods, depending on the study.

Analyses of colostral samples in the current survey resulted in values that were higher than those reported by Foley and Otterby (1978) for all minerals except copper and manganese. Kume and Tanabe (1993) indicated that minerals were highest in colostrum to provide calves with minerals after birth. Although most minerals are found in sufficient amounts in colostrum, concentrations depend on diet and parity of the dam, and this can result in mineral deficiencies in calves if supplementation is not provided (Kume and Tanabe, 1993).

\section{Survey Results}

Management of dry cows (Table 2) included vaccinations, housing, and supplemental vitamins, among other items. Straw was the predominant bedding material used in maternity pens (55\%), similar to previous survey results in which $57.2 \%$ of farms also used straw (Heinrichs et al., 1987). This was likely due to the cost and availability of straw in the Northeast at the time the surveys were conducted. All farms surveyed vaccinated dry cows; of these farms, $29 \%$ used vaccines for J-5 Escherichia coli bacteria and bovine viral diarrhea. Properly timed vaccinations increase the transfer of Ig specific for diseases and enhance the protection of calves through passive transfer, thereby improving the quality of the colostrum.

The amount, timing, and delivery of colostrum to heifer calves were surveyed (Table 3). Calves were fed by bottle on $87 \%$ of farms, and only 1 farm allowed calves to nurse the dam. This is an improvement from a previous Pennsylvania survey, which reported $22 \%$ of calves nursing off the dam unassisted (Heinrichs et al., 1987), and from the 2002 NAHMS study, in which $30.5 \%$ calves nursed.

Calves need to be fed colostrum in a timely manner, and most farms provide calves with colostrum within $4 \mathrm{~h}$ of birth. In Pennsylvania, calves received colostrum an average of $2.7 \mathrm{~h}$ after birth, and in Alberta $60 \%$ of calves received colostrum within $4 \mathrm{~h}$ (Heinrichs et al., 1987). In the current study, $43.6 \%$ of farms fed calves colostrum within $2 \mathrm{~h}$ after birth, and $51 \%$ fed colostrum between 2 and $6 \mathrm{~h}$ after birth.

In the current survey, calves were fed an average of 2 to $4 \mathrm{~L}$ of first-milking colostrum for the first feeding on $57 \%$ of farms; however, $37 \%$ fed $1.89 \mathrm{~L}$ or less for the first feeding. Previous survey results are similar, with an average of $2.8 \mathrm{~kg}$ fed for the first feeding (Heinrichs et al., 1987). Additionally, only $74 \%$ of farms in the current survey fed a second feeding of first-milking colostrum. The amount that calves were fed for the first feeding and whether a second feeding was fed were positively related $(P<0.05)$, and $9 \%$ of farms that fed $1.89 \mathrm{~L}$ or less for the first feeding did not feed a second feeding of first-milking colostrum, which could dramatically increase the chance for failure of passive transfer and subsequently raise the risk of mortality (Weaver et al., 2000).

The handling, storing, and milking of colostrum were also reported (Table 4). Use of frozen colostrum increased from $22 \%$ in a survey conducted by Heinrichs et al. (1987) to $38 \%$ currently, indicating increased awareness of the importance of timely colostrum feeding.

\section{Correlations Between Nutrients and Survey Questions}

Nutrient composition was compared with survey results; however, there were few statistically significant correlations. Farms with herd average SCC $<200,000$ in the month before samples were collected had colostrum with significantly greater tocopherol, vitamin A, potassium, $\mathrm{IgG}_{2}$, and TS $(6.38 \pm 0.82 \mu \mathrm{g} / \mathrm{g}, 3.61 \pm 0.42 \mu \mathrm{g} /$ $\mathrm{g}, 1,722.56 \pm 183.55 \mathrm{mg} / \mathrm{kg}, 7.27 \pm 0.61 \mathrm{mg} / \mathrm{mL}$, and $30.29 \pm 1.25 \%$, respectively) than farms with SCC $>200,000(4.22 \pm 0.61 \mu \mathrm{g} / \mathrm{g}, 2.63 \pm 0.31 \mu \mathrm{g} / \mathrm{g}, 5,787.86$ $\pm 203.38 \mathrm{mg} / \mathrm{kg}, 5.15 \pm 0.46 \mathrm{mg} / \mathrm{mL}$, and $25.75 \pm 0.95 \%$, respectively). The colostrum of cows without mastitis has been reported to contain numerically greater concentrations of vitamin $A$ and $\beta$-carotene than the colostrum of mastitic cows (Johnston and Chew, 1984). This indicates that cows housed at dairies with lower SCC counts may produce colostrum that is higher in nutrient 
Table 2. Survey responses regarding management of dry cows and heifers before calving by herd size (small, $\leq 100$ cows; medium, 101 to 200 cows; large, $\geq 200$ cows)

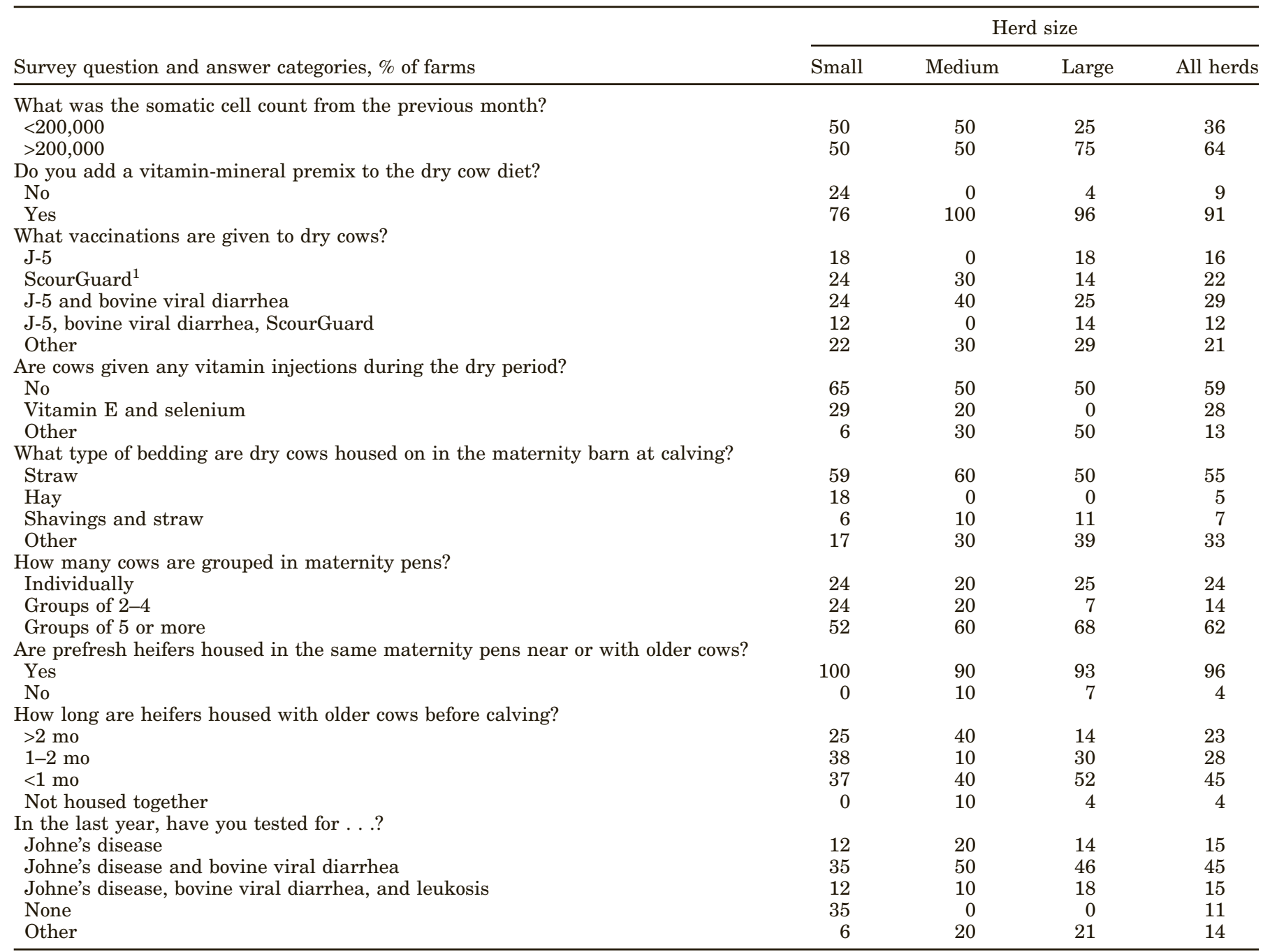

${ }^{1}$ ScourGuard, Pfizer Inc., New York, NY.

quality. In contrast, niacin was found in significantly greater concentrations $(P<0.02)$ for farms with SCC $>200,000(0.45 \pm 0.07 \mu \mathrm{g} / \mathrm{mL})$ compared with farms with $\mathrm{SCC}<200,000(0.23 \pm 0.07 \mu \mathrm{g} / \mathrm{mL})$.

Means for lactose were greater for farms that did not give vitamin injections than for farms that used vitamin injections during the dry period $(3.29 \pm 0.28 \%$ and 2.41 $\pm 0.09 \%$, respectively; $P<0.004)$. The reason for this correlation is unknown.

\section{Correlations by Farm Size}

Farm size plays a role in the management of farms and may reflect on colostrum quality. The current survey included 17 farms with $\leq 100$ cows, 10 farms with 101 to 200 cows, and 28 farms with $\geq 201$ cows. Fewer small farms fed a vitamin-mineral premix to dry cows compared with farms with medium and large herds $(P$ $<0.04)$. A colostrometer was used on $43 \%$ of large farms compared with $10 \%$ of medium farms and $12 \%$ of small farms. Eleven percent of large farms reported using a pasteurizer, whereas no farms with $\leq 200$ cows used a pasteurizer $(P<0.09)$. This may be due to the availability of resources and the use of larger equipment on larger farms. Farms that used a pasteurizer also used a colostrometer $(P<0.01)$ and did not feed colostrum to calves from their respective dams $(P<0.02)$.

Larger farms also stored more colostrum. Of small farms, 59\% reported not storing any colostrum compared with $21 \%$ of large farms. This is most likely because smaller farms had fewer calves and fed colostrum to calves directly from their respective dams. Eightynine percent of small and medium farms reported feeding colostrum to calves from their respective dams com- 
Table 3. Survey responses regarding feeding of colostrum to newborn heifer calves by herd size (small, $\leq 100$ cows; medium, 101 to 200 cows; large, $\geq 200$ cows)

\begin{tabular}{|c|c|c|c|c|}
\hline \multirow[b]{2}{*}{ Survey question and answer categories, $\%$ of farms } & \multicolumn{4}{|c|}{ Herd size } \\
\hline & Small & Medium & Large & All herds \\
\hline \multicolumn{5}{|c|}{ How much colostrum do heifer calves receive for the first feeding? } \\
\hline $1.89 \mathrm{~L}$ or less & 29 & 56 & 36 & 37 \\
\hline 1.89 to $3.79 \mathrm{~L}$ & 59 & 44 & 60 & 57 \\
\hline $3.79 \mathrm{~L}$ or more & 12 & 0 & 4 & 6 \\
\hline \multicolumn{5}{|l|}{ Do calves receive 2 feedings of colostrum? } \\
\hline Yes & 82 & 50 & 71 & 74 \\
\hline No second feeding & 18 & 50 & 29 & 26 \\
\hline \multicolumn{5}{|l|}{ How is colostrum fed to calves? } \\
\hline Allowed to nurse off the dam & 0 & 0 & 4 & 2 \\
\hline Hand-fed from bucket or bottle & 100 & 80 & 82 & 87 \\
\hline Hand-fed using esophageal feeder & 0 & 20 & 14 & 11 \\
\hline \multicolumn{5}{|l|}{ When are heifer calves fed colostrum? } \\
\hline Within the first $2 \mathrm{~h}$ & 41 & 40 & 46 & 44 \\
\hline Within 2 to $6 \mathrm{~h}$ & 47 & 60 & 50 & 51 \\
\hline After $6 \mathrm{~h}$ & 12 & 0 & 4 & 5 \\
\hline \multicolumn{5}{|c|}{ When are heifer calves fed the second feeding of colostrum? } \\
\hline 6 to $8 \mathrm{~h}$ later & 24 & 0 & 21 & 20 \\
\hline 8 to $12 \mathrm{~h}$ later & 41 & 50 & 50 & 53 \\
\hline 12 to $24 \mathrm{~h}$ later & 6 & 0 & 0 & 2 \\
\hline Not fed a second feeding & 29 & 50 & 29 & 25 \\
\hline
\end{tabular}

Table 4. Survey responses regarding management and storage of colostrum by herd size (small, $\leq 100$ cows; medium, 101 to 200 cows; large, $\geq 200$ cows)

\begin{tabular}{|c|c|c|c|c|}
\hline \multirow[b]{2}{*}{ Survey question and answer categories, \% of farms } & \multicolumn{4}{|c|}{ Herd size } \\
\hline & Small & Medium & Large & All herds \\
\hline \multicolumn{5}{|c|}{ On average how long after calving is a cow milked for first colostrum? } \\
\hline Immediately, $<1 \mathrm{~h}$ & 12 & 10 & 0 & 6 \\
\hline 1 to $2 \mathrm{~h}$ & 29 & 10 & 11 & 16 \\
\hline 2 to $6 \mathrm{~h}$ & 35 & 60 & 68 & 56 \\
\hline$>6 \mathrm{~h}$ & 24 & 20 & 21 & 22 \\
\hline \multicolumn{5}{|c|}{ If colostrum is stored, what kind of container is it stored in? } \\
\hline Open-topped container & 6 & 0 & 11 & 7 \\
\hline Closed container & 35 & 50 & 68 & 55 \\
\hline Not stored & 59 & 50 & 21 & 38 \\
\hline \multicolumn{5}{|l|}{ How is colostrum stored after milking? } \\
\hline Frozen & 35 & 40 & 39 & 38 \\
\hline Refrigerator & 6 & 10 & 36 & 22 \\
\hline Stored without refrigeration & 0 & 0 & 4 & 2 \\
\hline Not stored & 59 & 50 & 21 & 38 \\
\hline \multicolumn{5}{|l|}{ Are calves fed colostrum from their own dam? } \\
\hline Yes & 88 & 80 & 43 & 65 \\
\hline No & 12 & 20 & 57 & 35 \\
\hline \multicolumn{5}{|l|}{ Is colostrum used from first-calf heifers? } \\
\hline Yes & 88 & 70 & 75 & 78 \\
\hline \multicolumn{5}{|c|}{ No-Is there a source of stored colostrum (fresh or frozen)? } \\
\hline Yes & 0 & 10 & 11 & 7 \\
\hline No & 12 & 20 & 14 & 15 \\
\hline \multicolumn{5}{|l|}{ Is first-milking colostrum pooled? } \\
\hline Yes & 18 & 0 & 21 & 16 \\
\hline No & 82 & 100 & 79 & 84 \\
\hline \multicolumn{5}{|l|}{ Is a colostrum supplement used in addition to colostrum? } \\
\hline Yes & 6 & 20 & 25 & 18 \\
\hline No & 94 & 80 & 75 & 82 \\
\hline \multicolumn{5}{|l|}{ Do you use a colostrometer? } \\
\hline Yes & 12 & 10 & 43 & 27 \\
\hline No & 88 & 90 & 57 & 73 \\
\hline \multicolumn{5}{|l|}{ Is a pasteurizer used on the farm? } \\
\hline Yes & 0 & 0 & 11 & 5 \\
\hline No & 100 & 100 & 89 & 95 \\
\hline
\end{tabular}


pared with only $43 \%$ of large farms. This result is supported by findings of the NAHMS (2002) survey, which showed that $65.4 \%$ of farms with less than 100 cows did not store colostrum compared with $44.6 \%$ of farms with 100 to 499 cows. This may lead to higher calf mortality on small farms, as found by the NAHMS (2002) survey, which reported that calf mortality decreased as herd size increased.

Large farms tended to milk cows later after calving than did medium and small farms $(P<0.12)$. No large farms reported milking cows within 1 to $2 \mathrm{~h}$ after calving, compared with 10 to $12 \%$ of farms with $\leq 200$ cows. Sixty-eight percent of cows on large farms were milked between 2 to $6 \mathrm{~h}$ after calving compared with $60 \%$ of medium farms and $35 \%$ of small farms. Furthermore, $67 \%$ of large farms reported that the interval between calving and first milking was similar, whether cows calved during the day or at night. In contrast, $35 \%$ of small farms and $40 \%$ of medium farms reported that this interval was longer if cows calved at night. This is an example of the difference in resources on small farms, which, although efficient during the day, usually have less labor at night. Therefore, cows must wait to be milked until the day crew begins work.

Analyzing farms by different size categories showed some differences; however, farms with $\leq 100$ cows and with 101 to 200 cows were more similar than farms with $\geq 201$ cows. In summary, we could generalize that smaller farms with fewer than 100 or 200 cows were managed differently from their larger counterparts. Differences in resources, including the availability of workers, finances, and feed, resulted in significant differences in management and colostrum composition.

This farm survey covered the management of colostrum and aspects of dry cow management. A better understanding of how management practices influence colostrum quality can help managers and consultants focus on areas within colostrum management and feeding that need improvement. A previous survey reported improvements in colostrum management and feeding when producers were provided with information regarding calf health (Heinrichs and Kiernan, 1994). After receiving feedback and management recommendations, producers increased the colostrum feeding volume from 2.7 to $3.5 \mathrm{~kg}$ and decreased the time of feeding after birth from 2.6 to $2.4 \mathrm{~h}$.

\section{CONCLUSIONS}

The current survey revealed certain improvements in the management and feeding of colostrum. The number of farms currently storing frozen colostrum has increased compared with previous surveys. More farms are separating calves from their dams and manually feeding colostrum, which enhances passive transfer. Several nutrients in colostrum have also increased in concentration, indicating that dry cows may be receiving diets that more adequately meet their nutrient requirements.

Differences were found in management and nutrient concentrations between small and large farms. Larger farms reported longer times of milking colostrum after calving, higher SCC, and a lower nutrient content of colostrum compared with small farms. However, more large farms stored colostrum, fed a mineral-vitamin supplement, and used a colostrometer compared with small farms. Improvements in colostrum management and feeding can be better focused by considering farm size.

Nevertheless, there is still room for improvement, as indicated by the steadily increasing calf mortality rate reported in the NAHMS (2002) survey. Education in colostrum management and feeding needs to be emphasized and must be continued to keep improving the care of dairy calves.

\section{ACKNOWLEDGMENTS}

Partial funding for this research was provided by the Pennsylvania Department of Agriculture, Animal Health Commission. Sincere appreciation is extended to the dairy farmers interviewed for the study, to the various county educators who assisted in farm identification, and to Maria Long for laboratory assistance.

\section{REFERENCES}

Albala-Hurtado, S., M. T. Veciania-Nogues, M. Izquierdo-Pulido, and A. Marine-Font. 1997. Determination of water-soluble vitamins in infant milk by high-performance liquid chromatography. J. Chromatogr. 778A:247-253.

AOAC. 1975. Official Methods of Analysis. AOAC, Washington, DC. Arnaud, J., I. Fortis, S. Blachier, D. Kia, and A. Favier. 1991. Simultaneous determination of retinol, $\alpha$-tocopherol and $\beta$-carotene in serum by isocratic high-performance liquid chromatography. J. Chromatogr. B 572:103-116.

Carstens, G. E., D. E. Johnson, M. D. Holland, and K. G. Odde. 1987. Effects of prepartum protein nutrition and birth weight on basal metabolism in bovine neonates. J. Anim. Sci. 65:745-751.

Dietz, R. E., J. B. Hall, W. D. Whittier, F. Elvinger, and D. E. Eversole. 2003. Effects of feeding supplemental fat to beef cows on cold tolerance in newborn calves. J. Anim. Sci. 81:885-894.

Eitenmiller, R. R., and W. O. Landen Jr., ed. 1999. Vitamin Analysis for the Health and Food Sciences. CRC Press, Boca Raton, FL.

Feitosa Teles, F. F., C. K. Young, and J. W. Stull. 1978. A method for the rapid determination of lactose. J. Dairy Sci. 61:506-508.

Foley, J. A., and D. E. Otterby. 1978. Availability, storage, treatment, composition, and feeding value of surplus colostrum: A review. J. Dairy Sci. 61:1033-1060.

Halliday, R., A. J. F. Russel, M. R. Williams, and J. N. Peart. 1978. Effects of energy intake during late pregnancy and of genotype on immunoglobulin transfer to calves in suckler herds. Res. Vet. Sci. 24:26-31.

Heinrichs, A. J., and N. E. Kiernan. 1994. Initial results of a statewide extension program in calf and heifer management in Pennsylvania. J. Dairy Sci. 77:338-342. 
Heinrichs, A. J., N. E. Kiernan, R. E. Graves, and L. J. Hutchinson. 1987. Survey of calf and heifer management practices in Pennsylvania dairy herds. J. Dairy Sci. 70:896-904.

Johnston, L. A., and B. P. Chew. 1984. Peripartum changes of plasma and milk vitamin $\mathrm{A}$ and $\beta$-carotene among dairy cows with or without mastitis. J. Dairy Sci. 67:1832-1840.

Kume, S. I., and S. Tanabe. 1993. Effect of parity on colostral mineral concentrations of Holstein cows and value of colostrum as a mineral source for newborn calves. J. Dairy Sci. 76:1654-1660.

Masseyeff, R. F., and M. C. Zisswiller. 1969. A versatile method of radial immunodiffusion assay employing microquantities of antisera. Annal. Biochem. 30:180-184.

Masson, P. L., and J. F. Heremans. 1971. Lactoferrin in milk from different species. Comp. Biochem. Physiol. 39B:119-129.

Parrish, D. B., G. H. Wise, J. S. Hughes, and F. W. Atkeson. 1950. Properties of the colostrum of the dairy cow. V. Yield, specific gravity and concentrations of total solids and its various components of colostrum and early milk. J. Dairy Sci. 33:457-465.

Porter, P. 1972. Immunoglobulins in bovine mammary secretions. Immunology 23:225-238.

Pritchett, L. C., C. C. Gay, T. E. Besser, and D. D. Hancock. 1991. Management and production factors influencing immunoglobulin $\mathrm{G}_{1}$ concentration in colostrum from Holstein cows. J. Dairy Sci. 74:2336-2341.

Quigley, J. D., III, and J. J. Drewry. 1998. Nutrient and immunity transfer from cow to calf pre- and postcalving. J. Dairy Sci. 81:2779-2790.

Robblee, E. D., P. S. Erickson, N. L. Whitehouse, A. M. McLaughlin, C. G. Schwab, J. J. Rejman, and R. E. Rompala. 2003. Supplemental lactoferrin improves health and growth of Holstein calves during the preweaning phase. J. Dairy Sci. 86:1458-1464.

Roderuck, C. E., M. N. Coryell, H. H. Williams, and I. G. Macy. 1945. Human milk studies. Free and total riboflavin contents of colostrum and mature human milk. Am. J. Dis. Child. 70:171-175.

Roy, J. H. B. 1990. The Calf. 5th ed. Vol. 1. Butterworths, London, UK.

SAS Institute. 2002. User's Guide: Statistics. SAS Institute Inc., Cary, NC.

Speicher, J. A., and R. E. Hepp. 1973. Factors associated with calf mortality in Michigan dairy herds. J. Am. Vet. Med. Assoc. 162:463-466.
Spielman, A. A., J. W. Thomas, J. K. Loosli, C. L. Norton, and K. L. Turk. 1946. The placental transmission and fetal storage of vitamin A and carotene in the bovine. J. Dairy Sci. 29:707-715.

Stewart, J., and J. W. McCallum. 1938. The vitamin A content of the colostrum of dairy cows. J. Agric. Sci. 28:428-436.

Svensson, C., K. Lundborg, U. Emanuelson, and S. Olsson. 2003. Morbidity in Swedish dairy calves from birth to 90 days of age and individual calf-level risk factors for infectious diseases. Prev. Vet. Med. 58:179-197.

Tsuji, S., Y. Hirata, and F. Mukai. 1990. Comparison of lactoferrin content in colostrum between different cattle breeds. J. Dairy Sci. 73:125-128.

USDA. 2002. Part I: Reference of Dairy Cattle Health and Health Management Practices in the United States. APHIS, Fort Collins, $\mathrm{CO}$.

USDA. 2003. Pennsylvania Agricultural Statistics Report. National Agricultural Statistics Service, Washington, DC.

US EPA (US Environmental Protection Agency). 1986. Test Methods for Evaluating Solid Waste. 3rd ed. Vol. 1A. EPA/SW-846. Nat. Tech. Inf. Serv., Springfield, VA.

Weaver, D. M., J. W. Tyler, D. C. VanMetre, D. E. Hostetler, and G. M. Barrington. 2000. Passive transfer of colostral immunoglobulins in calves. J. Vet. Intern. Med. 14:569-577.

Wehr, H. M., and J. F. Frank. 2004. Standard Methods for the Examination of Dairy Products. 17th ed. Am. Public Health Assoc., Washington, DC.

Weiss, W. P., D. A. Todhunter, J. S. Hogan, and K. L. Smith. 1990. Effect of duration of supplementation of selenium and vitamin E on periparturient dairy cows. J. Dairy Sci. 73:3187-3194.

Yoshida, S., Z. Wei, Y. Shinmura, and N. Fukunaga. 2000. Separation of lactoferrin-a and -b from bovine colostrum. J. Dairy Sci. 83:2211-2215.

Zabielski, R., I. Le Huerou-Luron, and P. Guilloteau. 1999. Development of gastrointestinal and pancreatic functions in mammalians (mainly bovine and porcine species): Influence of age and ingested food. Reprod. Nutr. Dev. 39:5-26.

Zanker, I. A., H. M. Hammon, and J. W. Blum. 2000. Beta-carotene, retinol and alpha-tocopherol status in calves fed the first colostrum at $0-2,6-7,12-13$ or $24-25$ hours after birth. Int. J. Vitam. Nutr. Res. 70:305-310. 